Revista Eletrônica Geografar, Curitiba, v. 2, Resumos do VI Seminário Interno de Pós-Graduação em Geografia, p. 26-26. Junho/2007

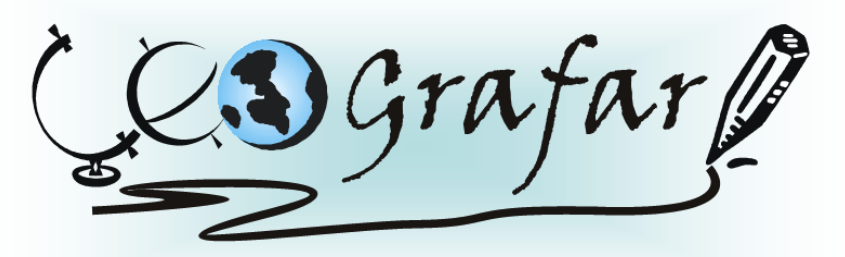

Revista Eletrônica do Programa de Pós-Graduação em Geografia - UFPR

\title{
O ESPAÇO DE REPRESENTAÇÃO NO CONTESTADO
}

\section{FABIANO FELDHAUS ${ }^{1}$}

A Guerra do Contestado trouxe elementos significativos à ocupação humana ocorrida na região antes, durante e pós-guerra. Também apresenta reflexos, presentes nos dias de hoje, envolvendo a relação homem - natureza; relações de ordem capitalistas - políticas envolvendo interesses e questões peculiares. Um desses elementos que no presente trabalho iremos abordar, diz respeito à religiosidade. E assim apresentamos duas formas de expressar o modo de viver essa religiosidade: uma, ortodoxa, que era o jeito dos que viviam nos arredores das Igrejas Franciscanas e nelas iam "piedosamente" confessar seus pecados; e uma outra, a rústica, vivida por àqueles que seguiam o Monge e seus ensinamentos, sem necessariamente um templo, pois o seu templo era a natureza, o seu teto. Os caboclos da área contestada, ao criarem uma irmandade, estavam criando uma visão do mundo norteadora do movimento, organizados em vários redutos, mas com objetivos iguais. Faremos a análise com base na teoria das representações sociais elaborada primeiramente por Moscovici que a compreende como sendo o estudo de como e por que as pessoas partilham o conhecimento e desse modo constituem sua realidade comum, de como transformam idéias em práticas. O objetivo de se fazer um trabalho sob a ótica da religiosidade presente na Guerra do Contestado é o de: estudar, analisar e verificar a relação que envolveu o catolicismo popular versus o catolicismo romano. Devido à uma história de colonização e migração forte, o espaço catarinense e paranaense - inclusive o do Vale do Contestado -, estão profundamente multiculturais.O entendimento dessa multiplicidade de condições deve ser analisado por meio da linha de pesquisa da Geografia da Religião que permitirá entendimentos das condicionantes históricas dos conflito e as marcas deixadas no território contestado e, especialmente, na organização do espaço religioso.

Palavras-chave: Espaço - Representação, Guerra do Contestado, Monges.

${ }^{1}$ Mestrando em Geografia - UFPR - email:fabiano.feldhaus@uol.com.br Orientador: SYLVIO FAUSTO GIL FILHO 